\title{
EFFECT OF RESIDENCE TIME ON PHOSPHATE DISTRIBUTION IN PHOSPHATE/COMPOST TREATED SOIL
}

\author{
M. El-Kherbawy*;Abou Seeda.M**;Taha.S;"Wahdan.R.R ${ }^{* * *}$ and Zaghloul.A.M ${ }^{* * * *}$ \\ *Soils Department, Cairo University, Cairo, Egypt. \\ ** Department of Plant Nutrition, N.R.C., Cairo, Egypt. \\ ***Soils \& Water Use Department, N.R.C., Egypt.
}

\section{ABSTRACT}

Sequential extraction technique of phosphorus using different extractant solutions were carried out to separate various pools of soil phosphorus such as (I) labile (plant available) $P_{i}$, (2) inorganic $P$ bound to $\mathrm{Fe}$ and $\mathrm{Al}$, (3) inorganic $P$ bound to $\mathrm{Ca}$ and $\mathrm{Mg}$, (4) organic $P$, and (5) residual $P$. The procedure were developed for natural amendments applied in this study containing compost $(C)$, phosphate Rock (PR), Citric acid (CA) in different combination treatments, to recognize plant available $P$ in readily available forms (water soluble and bicarbonate form), refractory forms (NaOH-P, Po, HCL Pi, residual-P). Moreover, the rate process of $P$ released from these systems was also determined to evaluate the rate distribution of $P$ in different forms as affected by compost treatments and residence time and subsequently $P$ availability in such systems.

The obtained results indicated that application of compost treated with $15 \% P R$ (T3), the best treatment in overall experiment, increased the extractable phosphorus extracted with $\mathrm{H}_{2} \mathrm{O}$ (WS) compared with the other treatments. The acidification of $P R$ by citric acid at different rates of 2 and 4 $\%$ treatments applied in sandy soil gradually increased the WS fraction compared with control (PR) through the incubation periods. The higher readily available $P$ was particularly observed after 30 and 120 days of soil incubation period. For these available forms, data showed that the extractable fraction of $P$ by sodium bicarbonate (the exchangeable form) varied significantly for the investigated treatments and time of incubation. The extractable fraction of $\mathrm{P}$ by $\mathrm{NaOH}$ gave the higher available values particularly for T3 compared with other treatments. In HCl-P pool, results indicated that application of citric acid at rate of $2 \%$ was also increased this pool by about $12 \%$ over control. Increasing rate up to $4 \%$ gradually increased this fraction by about $25 \%$ particularly after 15 days of incubation. Data observed that the extractable fractions of phosphorus by EDTA for the investigated treatments were varied according to treatment applied or incubation time of treatments; nevertheless higher values were noticed again in T3. The application of kinetic study applied in this experiment showed that the concentration of $P$ through the entire reaction time was varied in different forms into two stages which representing 
different mechanisms controlled $P$ distribution and $P$ availability through the entire reaction time.

Keywords: Residence time, phosphate distribution, phosphate/compost, treated soil

\section{INTRODUCTION}

Organic amendments applied in newly reclaimed areas including compost, farmyard manure, plant residues, food processing wastes, and sewage sludge. Many investigators have observed the effects of these amendments on physical, chemical, and biological properties. Although a wide variation in results exists in the literature on the effectiveness of composts to sustain the phosphorus $(\mathrm{P})$ nutrition of crops (Cabrera et al., 1991; Murillo et al., 1997), composting is increasingly recognized as a viable management method for solid organic wastes (He et al., 1996). One of the advantages of composting is the possible recycling of its end-product, composts, in agriculture or horticulture. Because of their high concentration in organic matter and nutrients, composts have been used for years as soil amendments.

A lot of research has focused on compost organic matter quality (Adani et al., 1997; Dinel et al.,1996, and on the forms and availability of compost N (Kuo, 1995), while little has been done to unravel the forms and availability of P. Composts may contain $\mathrm{P}$ taken up by plant in a soil-compost mixture vary from 10 to $264 \%$ of the amount of $\mathrm{P}$ taken up from a water soluble mineral fertilizer used as a reference when it riched with rock phosphate (PR) (Bezzola et al., 1994; Frei et al., 1997; Pommel, 1982; Sikora et al., 1991). This variability is always related to the wide range of compost-soil-plant systems studied and to the different methodologies used. Furthermore the results of a lot of these studies are difficult to interpret because of the lack of information on the forms of $\mathrm{P}$ in the added compost.

In addition, the effect of composting on phosphate forms and its availability remains unknown. Since excessive inputs of available $P$ in surface horizons of agricultural soils have to be avoided, because they lead to degradation of the quality of surface water (Sharpley \& Moyer, 2000), a prerequisite for using compost in a sustainable way is to quantify the amount of $\mathrm{P}$ which could be taken up by crops. Until now, chemical extraction methods have been used to assess phosphate availability in composts (Kuo, 1995; McCoy et al., 1986; Pommel, 1982). All these studies considered implicitly that the total compost P could be divided in two pools: one containing available forms and other containing unavailable forms. It has been shown however that in soils, phosphate rocks and sewage sludges, such an arbitrary division cannot be made and that a continuum of mobility exists between inorganic $\mathrm{P}$ (Pi) present in the soil solution and $\mathrm{P} i$ located in the solid phase (Fardeau, 1996; Frossard et al., 1996; Lookman et al., 1996).

Sequential fractionation techniques are being used increasingly to provide more useful assessments of soil nutrients whether macro and micronutrients such as $\mathrm{P}$ distribution (Zaghloul, 1998), Lead (Pb) and Zinc ( $\mathrm{Zn})$ heavy metals distribution 
(Zaghloul, et al., 2006), than is possible with single extractions or total metal concentrations alone. In addition to that, ion fractionation technique is a fairly widely used for understanding the mechanisms of its distribution in different soil system and help to assess bioavailability of trace metals in soils. Sequential P extraction techniques based on the method developed by Chang and Jackson (1957) has been widely used to examine biogeochemical cycling and availability of P. De Groot and Golteman (1990) contend that commonly used fractionation schemes which use $\mathrm{NaOH}$ to extract Fe-bound $\mathrm{P}$ and $\mathrm{HCI}$ to extract Ca-bound $\mathrm{P}$, under estimate the amount of $\mathrm{P}$ bound to $\mathrm{Fe}$ and over estimate $\mathrm{P}$ bound to $\mathrm{Ca}$ minerals, when compared with the methods that utilize selective chelating agents (Golterman and Booman,1988). They also compared an extraction using $\mathrm{NaOH}$ to extract Fe-bound $\mathrm{P}$ followed by HCI to extract Ca-bound P (Hieltjes and Lijklema, 1980) with their method using $0.02 \mathrm{M}$ Ca-NTA with dithionate to extract Fe bound $\mathrm{P}$ followed by 0.05 $\mathrm{M}$ Na-EDTA to extract Ca-bound P. They found that estimates of Fe-bound P were greater using their approach, which resulted in lower estimates of Ca-bound $\mathrm{P}$. They also suggest that this was due to the transformation of Fe-bound $\mathrm{P}$ to Ca-bound $\mathrm{P}$ driven by the $\mathrm{pH}$ change associated with the $\mathrm{NaOH}$ extraction step.

In this paper, the main objectives are: (1) To studying $\mathrm{P}$ distribution into different pools in sandy soil treated with RP enriched compost. (2) To declare the effect of acidification of PR with $\mathrm{CA}$ at different rates on $\mathrm{P}$ distribution in the amended soil. (3) Understanding P availability through $\mathrm{P}$ distribution into different polls. (4) To represent the effect of residence time on rate of $\mathrm{P}$ mobile to different pools. Successive or sequential extraction procedures applied in this experiment using natural amendments may improve the predictive capacity of the tests considerably by removing a greater proportion of total $\mathrm{P}$ without achieving complete PR dissolution.

\section{MATERIALS AND METHODS}

\section{Soil sample}

In this study, topsoil $(0-30 \mathrm{~cm})$ of surface sandy soil was collected from ElKefaah valage, EL-Behera Governorate. This soil is characterized by pH: 8.53; EC: $0.65 \mathrm{dS} \mathrm{m}^{-1}$ at $25^{\circ} \mathrm{C}$; clay content $2.3 \%$; sand content: $93 \%$; silt $4.7 \mathrm{CaCO}_{3}$ content $0.90 \%$; CEC $3.21 \mathrm{meq} 100 \mathrm{~g}^{-1}$; organic matter content $0.9 \%$; total N $241.5 \mathrm{ppm}$; total $\mathrm{P}_{2} \mathrm{O}_{5}$ and $\mathrm{K}_{2} \mathrm{O}$ were $60.17 \mathrm{ppm}$ and $329.5 \mathrm{ppm}$ respectively. Soil sample was air dried and ground to pass through a 2-mm sieve.

\section{Treatments and experimental design}

Fifty grams of oven-dried soil samples were weighed into $200 \mathrm{~mL}$ plastic bottles and mixed with the three Phosphocompost types $\left(\mathrm{T}_{1}-\mathrm{T}_{3}\right)$ treatments with different rates of phosphate rock presented in table1 the investigated material were treated with soil at rate of five tons per feddan. Also, the application of PR treated with CA at rates of 2 and $4 \%$ was investigated to evaluate the effect of acidification of PR on P distribution. The soil and treatments were thoroughly mixed, moistened to approximately $60 \%$ of water holding capacity (WHC)and incubated aerobically at 
$25^{\circ} \mathrm{C}$ for $1,2,4,8,12$, and 16 weeks. Distilled water was periodically added to maintain the mixtures at approximately $60 \%$ of field capacity throughout the study. At the end of each incubation period, treated soil samples were collected and prepared for fractionation study. Worth to mention that every treatment was triplicate

Table 1: Some chemical and nutritional properties of the studied Phosphocompost.

\begin{tabular}{|c|c|c|c|c|c|c|c|c|c|c|}
\hline \multirow{2}{*}{$\begin{array}{l}\text { Phosphocompost } \\
\text { sample } \\
\text { (PC) }\end{array}$} & \multirow{2}{*}{$\mathbf{C} / \mathbf{N}$} & \multicolumn{3}{|c|}{$\begin{array}{c}\text { Total } \\
\text { Macronutrients \% }\end{array}$} & \multicolumn{6}{|c|}{ Available Macronutrients } \\
\hline & & $\mathbf{N}$ & $\mathbf{P}$ & $\mathbf{K}$ & $\begin{array}{l}\mathbf{N} \\
(\%)\end{array}$ & & $\begin{array}{l}\mathbf{P} \\
\mathbf{p m})\end{array}$ & & $\begin{array}{c}\mathrm{K} \\
\mathbf{p p m})\end{array}$ & \\
\hline Compost10\%RP(T1) & $1: 18$ & 1.5 & 2.2 & 1.2 & 0.059 & & 600 & & 8000 & \\
\hline Compost15\%RP(T2) & $1: 22$ & 1.7 & 2.3 & 1.4 & 0.026 & & 000 & & 7000 & \\
\hline \multirow[t]{3}{*}{ Compost $20 \%$ RP(T3) } & $1: 24$ & 1.8 & 2.8 & 1.3 & 0.126 & & 500 & & 7450 & \\
\hline & pH & $\mathbf{E C}$ & \multicolumn{4}{|c|}{ Cations } & \multicolumn{4}{|c|}{ Anions } \\
\hline & & $\begin{array}{c}\mathbf{d S m} \\
\mathrm{m}^{-1} \\
(1: 20)\end{array}$ & $\mathbf{N a}^{+}$ & $\mathbf{K}^{+}$ & $\mathrm{Ca}^{++}$ & $\mathbf{M g}^{++}$ & $\mathrm{Co}_{3}^{--}$ & $\mathrm{HCO}_{3}^{-}$ & $\mathrm{Cl}^{-}$ & $\mathrm{So}_{4}^{--}$ \\
\hline Compost10\%RP(T1) & 9.4 & 1.4 & 3.1 & 11.6 & 1.70 & 1.3 & - & 3.0 & 8.2 & 6.5 \\
\hline Compost15\%RP(T2) & 8.4 & 0.9 & 3.5 & 9.0 & 2.40 & 2.1 & - & 2.7 & 5.5 & 8.8 \\
\hline Compost $20 \% R P(T 3)$ & 8.6 & 1.8 & 3.7 & 11.4 & 1.80 & 2.2 & - & 2.8 & 8.2 & 8.1 \\
\hline
\end{tabular}

\section{Phosphate distribution study}

In the studied samples $\mathrm{P}$ distributions were conducted according to Sui and Thompson (1999). After each incubation time, the following fractions were obtained: the water soluble (solution-P), exchangeable (NaHCO3-P), NaOH-P, Fe-Mn oxides, organic, and residual. The method could be summarized as follow:

(1) Solution P, by shaking $1 \mathrm{~g}$ soil in $10 \mathrm{~mL}$ redistilled water for $16 \mathrm{~h}$, centrifuging, filtering, and measuring $\mathrm{P}$ in the filtrate.

(2) $\mathrm{NaHCO}_{3}-\mathrm{P}$, by shaking the residue from (1) in $30 \mathrm{~mL}$ of $0.5 \mathrm{M} \mathrm{NaHCO}_{3}$ for $16 \mathrm{~h}$, centrifuging, filtering, and measuring $\mathrm{P}$ in the filtrate.

(3) $\mathrm{NaOH}-\mathrm{P}$, by shaking the residue from (2) in $30 \mathrm{~mL}$ of $0.1 \mathrm{M} \mathrm{NaOH}$, centrifuging, filtering, and measuring $\mathrm{P}$ in the filtrate after acidifying $5 \mathrm{~mL}$ (with concentrated $\mathrm{HCl}$ ) and centrifuging.

(4) Acid P, by shaking the residue from (3) in $30 \mathrm{~mL}$ of $1: 1$ mixture of $1 \mathrm{M} \mathrm{HCl} / 1 \mathrm{M}$ $\mathrm{H}_{2} \mathrm{SO}_{4}$, centrifuging, filtering, and measuring $\mathrm{P}$ in the filtrate.

(5) EDTA-P, Inorganic precipitate by shaking the residue with $0,05 \mathrm{M} \mathrm{Na}^{E_{D T A}}$ for $6 \mathrm{~h}$.

(6) Occluded-P The residue from Fe-Mn oxide fraction is extracted with $10 \mathrm{ml}$ of $(0.1 \mathrm{M}$ oxalic acid $+0.175 \mathrm{M}$ ammonium oxalate $\mathrm{pH} 3.25)$ and centrifuging.

(7) Residual $\mathrm{P}$, by refluxing the soil residue from (5) in $6 \mathrm{~mL}$ of a $5: 2$ mixture of concentrated $\mathrm{HNO}_{3}$ and $\mathrm{HClO}_{4}$, and determining $\mathrm{P}$ from the digest (Hedley et al, 1982). 
All P was determined calorimetrically according to Murphy and Riley (1962) after neutralization when necessary with dilute $\mathrm{HCl}$ and $\mathrm{NaOH}$ and the neutral $\mathrm{pH}$ indicated by the light yellow color of the solution in the presence of P-nitrophenol indicator. Absorbance for $\mathrm{P}$ was determined at a wavelength of $712 \mathrm{~nm}$ by spectrophotometer.

All measurements of $\mathrm{P}$ were done in triplicate, and data analysis such as standard division SD or regression analysis were performed using the statistical software SAS (SAS, 1985).

\section{RESULTS AND DISCUSSION}

Phosphorus fractionation is used to separate the various pools of soil $\mathrm{P}$. These forms can be grouped as follows: (1) Labile (plant available) Pi, (2) Inorganic P bound to Fe and $\mathrm{Al}$, (3) Inorganic $\mathrm{P}$ bound to $\mathrm{Ca}$ and $\mathrm{Mg}$, (4) Organic $\mathrm{P}$, and (5) Residual P. The fractionation procedure, developed for natural soil amendments applied to soil system, recognizes plant-available forms (water soluble and bicarbonate $\mathrm{P}$ ) and refractory forms (NaOH-P, NaOH-P, Sonic Po, $\mathrm{HCl} \mathrm{Pi,} \mathrm{Residual}$ $\mathrm{P}$ ) of soil $\mathrm{P}$ (Hedley et al., 1982). In this classification, plant-available or labile $\mathrm{P}$ includes the sum of $\mathrm{Pi}$ and $\mathrm{Po}$ and bicarbonate extractions, while refractory or unavailable $\mathrm{P}$ includes all of other fractions.

In fractionation procedure, inorganic and organic $\mathrm{P}$ in the soil solution is removed with a series of successively stronger reagents: water soluble, sodium bicarbonate $\left(0.5 \mathrm{M} \mathrm{NaHCO}_{3}\right)$, sodium hydroxide $(0.1 \mathrm{M} \mathrm{NaOH})$, hydrochloric acid $(1.0 \mathrm{M} \mathrm{HCl})$ and an acid digestion (Hedley et al., 1982). The labile $\mathrm{P}$ is available to microbial and vegetation communities in the short term because it quickly desorbs from the surface of soil particles. Non-labile $\mathrm{P}$ fractions are bound to soil particles and are not as readily available forms for plant uptake.

\section{Readily available Pools}

In most researches applied, sequential extraction were used to evaluate the distribution of phosphorus, it is assumed that water soluble or solution soil phosphorus and exchangeable pool are the most readily available forms for growing plants. However, barrier to investigate $\mathrm{P}$ distribution under this experimental condition Huguenin-Elie et al. (2003) asserted that only $10 \%$ of the $\mathrm{P}$ taken up by crops was drawn from readily available pools; the bulk was drawn from sparingly soluble pools as a result of solubulization induced by roots.

\section{a. Solution Soil Phosphorus}

Data in Figure 1 showed that the mean concentration of solution $\mathrm{P}$ at 1 day incubation time varied from 1.4 to $2.9 \mathrm{mg} \mathrm{kg}^{-1}$ however, at 15 day of incubation the same values were 6.1 to $8.3 \mathrm{mg} \mathrm{kg}^{-1}$ soil (Figure 1). The range of solution $\mathrm{P}$ pool at the 30 days incubation was 5.1 to $7.5 \mathrm{mg} \mathrm{kg}^{-1}$, and a similar narrow range of solution $\mathrm{P}$ was also found in 60, 90 and 120 days incubation time. According to standard division SD analysis, the variation between PR individually (control) and other 




Figure 1. Effect of treated PR applied to sandy soil on $P$ distribution at different incubation time. 
treatments at different incubation time was not significant in most cases. However, application of phosphate compost at $15 \% \mathrm{PR}$, increased solution $\mathrm{P}$ as compared with other treatments. Acidification of PR with 2 and $4 \%$ CA increased the water soluble P over control at different incubation times, at 90 days time of soil incubation the WS-P increased from $3.96 \mathrm{ppm}$ to $4.11 \mathrm{ppm}$ at rates of $2 \%$ and $4 \%$ CA respectively. Worth to mention that the mixture of $\mathrm{PR}$ and compost in this pool take the trend: $\mathrm{C}+\mathrm{PR} 15 \%$ $>\mathrm{C}+\mathrm{PR} 20 \%>\mathrm{C}+\mathrm{PR} 10 \%$.

\section{b. $\mathrm{NaHCO}-\mathrm{P}$}

The $\mathrm{NaHCO}_{3}-\mathrm{P}$ pool is readily available to plants (Bowman and Cole, 1978). As a general observation in this fraction, the extractable $\mathrm{P}$ by $\mathrm{NaHCO}_{3}$ was significantly varied due to the applied treatments and time of soil incubation. Data presented in figure 2 showed that all treatments applied significantly increased HCO3P. After 30 days of soil incubation, the application of phosphocompost at different rates of PR was significant led to increase the extractable phosphorus. It was also noticed that, such increment was pronounced effect in $\mathrm{T} 3(\mathrm{C}+15 \% \mathrm{PR})$ with an average of increase reached to $23 \mathrm{ppm}$ against 19 and $18.3 \mathrm{ppm}$ for $\mathrm{C}+20 \% \mathrm{PR}$ and $\mathrm{C}+$ $10 \% \mathrm{PR}$ respectively. Worth to mention that PR only gave the lowest value $17.8 \mathrm{ppm}$.

Through the entire time of soil incubation, results indicated that application of PR acidified by citric acid at different rates ( 2 and $4 \%$ ), were gradually increased the extractable P. Numerically, after 1 day of incubation the application of PR treated with $2 \% \mathrm{CA}$, increased the extractable P by about $14 \mathrm{mg} / \mathrm{kg}$. Increasing of CA to $4 \%$ gradually increased $\mathrm{HCO}_{3}-\mathrm{P}$ to $16 \mathrm{mg} / \mathrm{kg}$.

Concerning the effect of residence time, results indicated that in all treatments, increasing of incubation period up to 15 days led to gradually increase the $\mathrm{HCO}_{3}-\mathrm{P}$, the averages of increment were ranged between 100 and $108 \%$ as compared with the same treatments incubated for 1 day. This result may detect the readily available pool represented by this fraction give the higher performance after 15 days of Phosphocompost application. Nevertheless, at high incubation time (30-120) days PR treated with CA gave higher readily available $\mathrm{P}$ over control treatment (PR).

\section{NaOH-P fraction}

Sequential extraction procedures using $\mathrm{NaOH}$ extractant solution for removal of $\mathrm{P}$ in organic form have been used extensively for investigating the chemical partitioning of phosphorus in soils (Rodolphe et al., 2000). Results indicated that organic $\mathrm{P}$ fraction constituted the largest $\mathrm{P}$ fraction in different treatments applied in used soil and at different incubation times compared with other fractions. Moreover, in this fraction the differences observed among different treatments had a slightly significance with some exceptions. Data showed that this fraction represents about 5$16 \%$ of total $\mathrm{P}$ in different treatments, the variations observed were directly due to the investigated treatments applied and incubation time of treated soil. Data also indicated that the application rates of PR added to compost were directly influencing phosphorus extracted by $\mathrm{NaOH}$ extractant solution. 


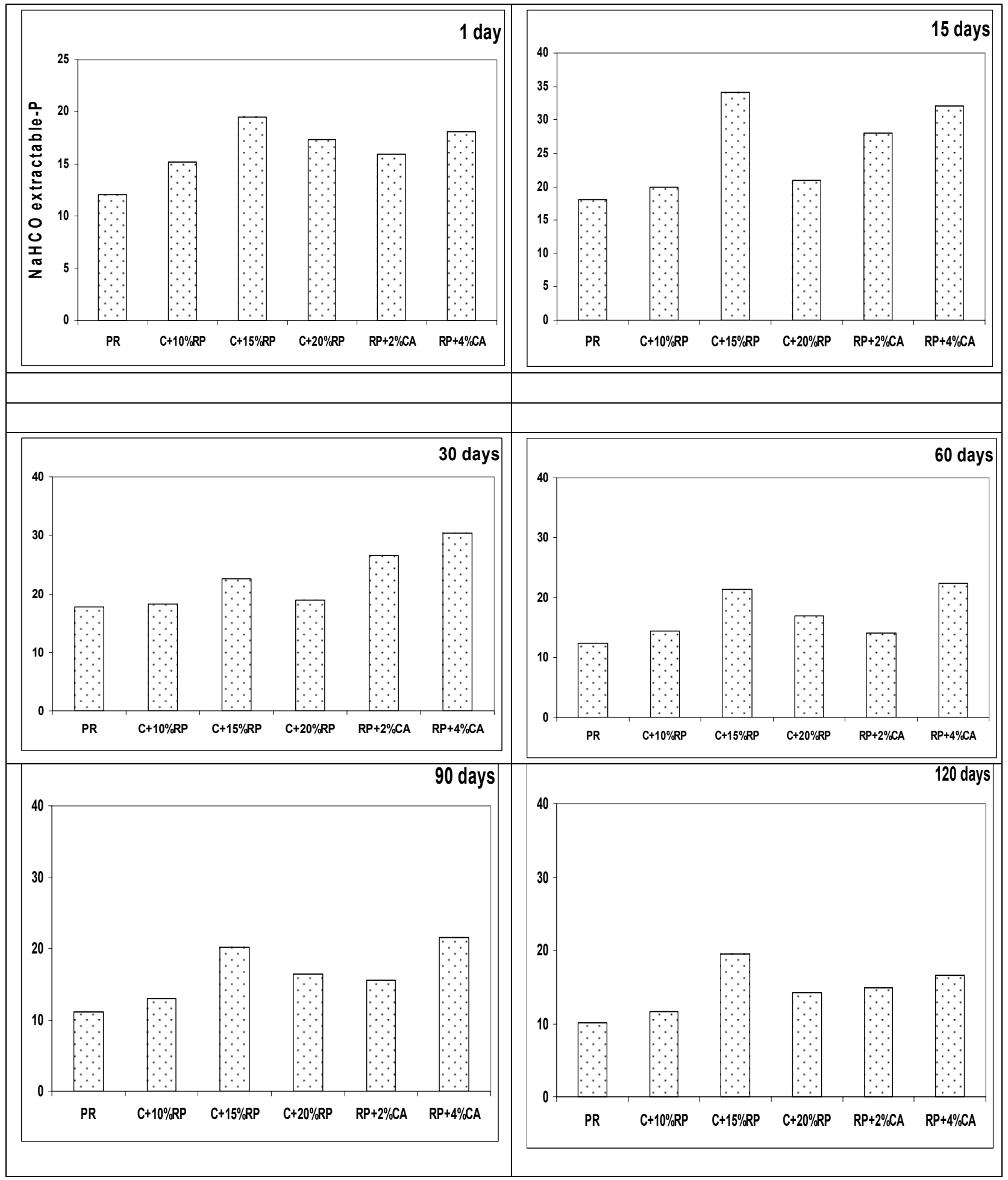

Figure 2. Exchangeable-P as affected by different treatments applied to sandy soil and time of soil incubation. 
Data plotted in Figure 3 represents the effect of incubation time on $\mathrm{P}$ extracted by $\mathrm{NaOH}$. After 15 days, the maximum $\mathrm{P}$ value was noticed in soil treated with compost $+15 \%$ PR, where the minimum one was in compost $+10 \%$ PR. By increasing the time of soil incubation to 120 days, a gradual decrease in extractable $\mathrm{P}$ was detected in all treatments. Numerically, data indicated that after 15 days, $\mathrm{NaOH}-\mathrm{P}$ were 25 and $31 \mathrm{ppm}$ in $\mathrm{T}_{2}$ and $\mathrm{T}_{4}$ against $36.1 \mathrm{mg} \mathrm{kg}^{-1}$ in $\mathrm{T}_{3}$. The respective values were decreased by about 8,11 and $10 \%$ after 120 days. The same trend was also noticed in the soil treated with PR acidified with CA. Data indicated that by increasing of the incubation time from 15 to 120 days, the extractable $\mathrm{P}$ was decreased from 34.2 and $36.3 \mathrm{ppm}$ to 24 and $25 \mathrm{ppm}$ in $\mathrm{T}_{5}$ and $\mathrm{T}_{6}$ respectively.

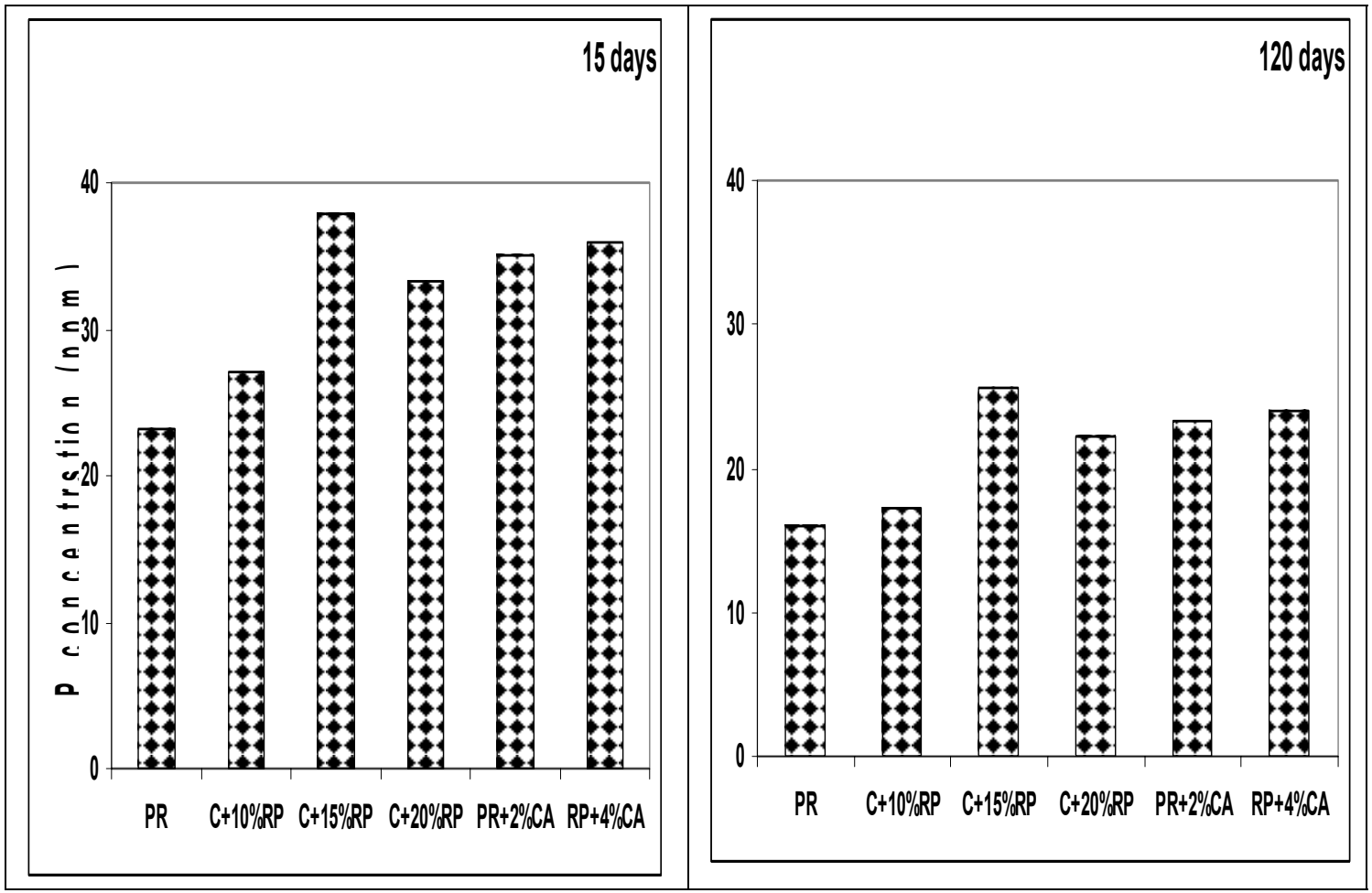

Figure 3. Extractable $\mathrm{NaOH}-\mathrm{P}$ as affected by different treatments applied at 15 and 120 days incubation periods.

The distribution in soil and availability of $\mathrm{NaOH}-\mathrm{P}$ pool to plant uptake have been reported by different authors. Saleque and Kirk, (1995) in their experiment, reported that rice did not absorb $\mathrm{P}$ from the $\mathrm{NaOH}-\mathrm{P}$ pool in some soils of the Philippines. Paniagua et al. (1995) studied the distribution of $\mathrm{P}$ pools as affected by the addition of organic active amendments during $10 \mathrm{yr}$ in a maize and bean rotation on a volcanic soil. They found that no differences in the size of the organic P pools as a result of the addition of organic amendments. Sui et al. (1999) observed that a slight increase in $\mathrm{NaOH}-\mathrm{P}$ due to biosolid application, but not significant. However, Sharpley (1985) reported that mineralization of organic $\mathrm{P}$ during the growing season, contributed a 
similar amount of $\mathrm{P}\left(20-74 \mathrm{~kg} \mathrm{P}^{-1}\right)$ as added in fertilizer (13-100 kg P ha- $\left.{ }^{1}\right)$, and was not inhibited by fertilizer P addition. On the other hand, McGill and Cole (1981) reported that the mineralizations of organic-p were occurred only when the supply of inorganic $\mathrm{P}$ is limited.

\section{D. $\mathrm{HCl}$-P fraction}

In sequential extraction procedures, the extractable fraction of phosphorus by $\mathrm{HCl}$ extraction solution dissolve $\mathrm{P}$ associated with calcium minerals (Concepcio' $\mathrm{n}$ and Delgado, 2005). Figure 4 depicted the HCl-P pool as affected by Phosphocompost and PR-CA treatments. Results indicated that the mean concentration of HCl-P ranged from 20 to $40 \mathrm{mg} \mathrm{kg}^{-1}$ over the entire incubation time and treatments applied. Despite the increased concentration of the HCl-P pool due to Phosphocompost applied to the studied soil at 10 and $20 \%$ PR without significant between these two treatments, the application of compost $(\mathrm{C})+15 \%$ PR again gave the highest extractable amount of phosphorus. After 15 days of soil incubation, data indicated that application of (compost $+15 \% \mathrm{PR}$ ) increased the HCl-P by about $41 \mathrm{ppm}$; the same pool values were 35.8 and $35.1 \mathrm{ppm}$ by application of $\mathrm{T} 2$ and $\mathrm{T} 3$. The control treatment (PR) value, however, was $26.2 \mathrm{mg} \mathrm{kg}^{-1}$.

Data also observed that application of CA to acidified PR in the studied soil sample also increased HCl-P pool over control. The application of rock phosphate treated with citric acid at rate of $2 \%$, increased the extractable phosphorus in this fraction by about $12 \%$ as compared with control after 15 days of incubation. Increasing the rate of citric acid to $4 \%$ gradually increased the extractable fraction of phosphate by about $25 \%$ compared with control treatment. The same trend was also observed in other incubation times tested for all treatments. On the other hand, increasing the incubation time from 15 to 120 days gradually decreased the HCl-P in all treatments even in PR (control treatment). This result will be discussed in more details in the part of the effect of incubation time on rate of $\mathrm{P}$ distribution in different fractions studied. However, in this part it should be mentioned here that after 120 days of incubation, the higher decreasing orders was observed in PR followed by $\mathrm{T} 1$ (compost $+10 \% \mathrm{PR})$ treatments and the lowest one was detected in T2(compost $+15 \%$ PR).

\section{Hardly available Pools E. EDTA phosphorus}

In this technique applied to study $\mathrm{P}$ fractionation, using of EDTA extractant solution applied to extract the chelating compounds for determine $\mathrm{P}$ related to $\mathrm{Fe}$ oxides and Ca-phosphates. It is a modified scheme of Golterman (1996) to study the sediment $\mathrm{P}$ fractionation developed. Data of this pool (Figure 5) showed that about $10-18 \%$ of total $\mathrm{P}$ was extracted through the entire reaction time of 120 days. The arrangement of these values was decreased from $10-15 \%$ of total $\mathrm{P}$ after 1 day of soil incubation. The decreasing order reached to $10-18 \%$ after 30 days and followed by increasing order to reach $10-18 \%$ of total $\mathrm{P}$ in all treatments applied. 




Figure 4. Extractable HCl-P during the incubation periods as affected by different treatments applied to sandy soil

The comparison between different treatments indicated that regardless the incubation time, $\mathrm{T}_{3}(\mathrm{C}+15 \% \mathrm{RP})$ always take the higher value as compared with other Phosphocompost treatments or even CA ones by about $15-20 \%$ and $30 \%$ respectively. Concerning CA treatment, data indicated that after 90 days of incubation using of PR acidified by $\mathrm{CA}$ at rate of $2 \%$ increase the extractable fraction of $\mathrm{P}$ by EDTA by about $41 \mathrm{mg} / \mathrm{kg}$. Increasing the rate of to $4 \%$, the extractable $\mathrm{P}$ reached to $44.5 \mathrm{mg} \mathrm{kg}^{-1}$, worth to mention that the control treatment T1 was $36 \mathrm{ppm}$. However, increasing the incubation time to 120 days, led to decrease the extractable $\mathrm{P}$ to 34 and $38 \mathrm{mg} \mathrm{kg}^{-1}$.

\section{F. Occluded Phosphorus}

Occluded P includes $\mathrm{P}$ on sites that are not accessible to outer solution (Torrent et al., 1990). From operational point of view, occluded $\mathrm{P}$ is considered the fraction released by the action of reductants after removing most of $\mathrm{P}$ adsorbed to Fe oxides and Fe-rich phosphate particles in previous extraction steps. 




Figure 5. Extractable EDTA-P during the incubation periods as affected by different treatments applied.

According to the numerical values of leached phosphate, data depicted in Figure 6 indicated that this pool represent about $12-25 \%$ of total P. After 1 day of incubation time, the occluded-P values decreased by about 12-21\%. After 15 days, gradual increase in this pool values was observed to reach the higher values (13-26\% of total P) by the end of incubation period of 120 days in all treatments.

In this pool, the application of Phosphocompost and CA to PR treated soils; results take the same trend in decreasing of $\mathrm{P}$ values by increasing the incubation time from 1 to 15 , followed by increasing the extractable fraction of phosphorus $\mathrm{P}$ during the incubation periods. Data in fig. 6 also indicated that in soil treated with compost $+15 \% \mathrm{PR}$, for example, the extractable-P were decreased from 60 to $51.3 \mathrm{ppm}$ by increasing the incubation time from 1 to 15 days, followed by gradually increasing order reached to $63.6 \mathrm{ppm}$ at 120 days. This treatment, however, showed the higher value as compared with other treatments during the incubation time.

According to the present data of this pool, a reverse trend was observed as compared with readily available forms. In other words occluded-P values were decreased after 1 and 15 days of incubation followed by increasing order in the rest of incubation times. In addition, for different treatments applied in this study it should be mentioned that the increasing order after 1 day of soil incubation takes the order: T3 $>$ $\mathrm{T} 4=\mathrm{T} 6>\mathrm{T} 5>\mathrm{T} 2>\mathrm{T} 1$. After 120 days the same order was $\mathrm{T} 3>\mathrm{T} 4>\mathrm{T} 6>\mathrm{T} 5>\mathrm{T} 2$ $>\mathrm{T} 1$. This trend may represent variation in behavior of CA treatments in this pool since T6 and T5 gave higher values as compared with T2 and T3 especially in the end of the incubation times. 


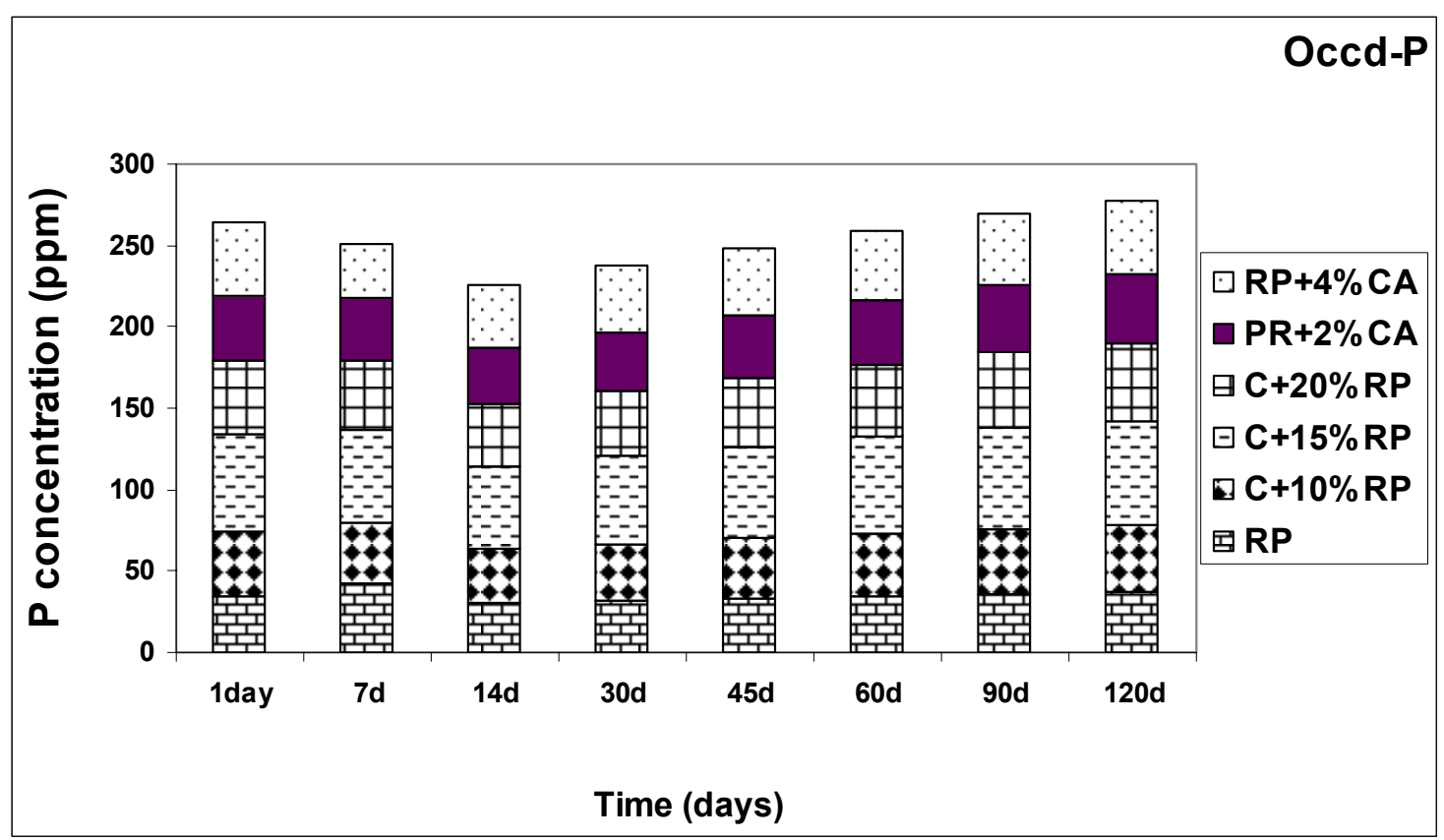

Figure 6. Occluded phosphate in different treatments applied at different incubation periods

\section{G. Residual Phosphorus}

This fraction contains naturally occurring minerals which may hold macronutrients within their crystalline matrix. Residual $P$ consistently represented the highest fraction of soil $\mathrm{P}$, without any exceptions. Also, this fraction considered to be a non- mobile fraction in the treated samples, which is least harmful fraction among all studied above. The metals concentration found in this fraction were higher than those observed in any of the preceding extractions.

Data in Table 2 observed that about $52-60 \%$ of the total phosphorus particularly in soil treated with rock phosphate was in the residual forms during the incubation periods. This result means that about $40-48$ of the total phosphorus was automatically distributed in other fractions; the available forms could be uptake by plants. Results also observed that application of Phosphocompost with different rates of rock phosphate gradually decrease the residual fraction of phosphorus. Such phenomenon could be related to the beneficial effects of organic matter in solubilization of most macro and micronutrients in soil system.

During composting processes, small chain of organic acids released in soil systems and could attack PR to be more soluble to considerable amount of phosphorus during the incubation periods. This excess amount of $\mathrm{P}$ will redistribute and recharged into different pools. Results noticed that the decreasing values of residual fraction were varied through the first 15 days of incubation, the maximum reduction was observed in this fraction in the soil treated with compost $+15 \%$ PR by about $20-25 \%$, followed by $27-34 \%$ for compost $+20 \% \mathrm{PR}$ and $35-44 \%$ for the soil treated with compost $+10 \% \mathrm{PR}$. It Also, the acidification of rock phosphate by citric acid at different rated ( $2 \%$ and $4 \%)$, gradually decrease the residual fraction of phosphorus. 
In this treatment the majority of phosphorus was mostly accounted $35-53 \%$ in the residual forms. As a general conclusion, it has been suggested that the greater proportion of $\mathrm{P}$ in the residual phase become unavailable in the soils (Ma and Rao, 1997). These observations are consistent with those obtained by Gupta and Chen, 1975; Tessier et al., 1979; and Ma and Rao 1997, they suggested that the majority of ions in soils and sediments were often of detrital nature. Also the obtained results were in agreement with that observed by Hickey and Kittrick (1984), Harrison (1987), Ma and Rao (1997).

Table 2: Effect of incubation time on the change of Residual-P in the treated soil.

\begin{tabular}{ccccccccc}
\hline Treatments & 1d & 7d & 14d & 30d & 45d & 60d & 90d & 120d \\
\hline RP & 58.37 & 54.59 & 52.08 & 53.46 & 55.49 & 56.01 & 57.65 & 59.09 \\
C+10\%RP & 41.26 & 40.22 & 34.75 & 36.83 & 38.41 & 39.67 & 42.06 & 43.77 \\
C+15\%RP & 22.85 & 21.96 & 19.68 & 20.46 & 21.42 & 22.19 & 23.52 & 24.96 \\
C+20\%RP & 32.56 & 30.46 & 27.48 & 29.13 & 30.33 & 31.07 & 32.71 & 33.56 \\
PR+2\%CA & 51.75 & 49.22 & 44.11 & 45.10 & 47.03 & 49.84 & 51.33 & 52.89 \\
RP+4\%CA & 43.31 & 42.14 & 36.78 & 37.58 & 38.84 & 41.63 & 42.74 & 44.07 \\
\hline
\end{tabular}

The fractionation of phosphorus by various extractant reagents always reflected lower concentration of the extractable fraction as compared with the residual one. This finding may be due to the lower solubility product of phosphate in soil, since the chemical composition of the rock phosphate mainly hydroxyl apatite and fluroapatite.

Effect of residence time on $P$ redistribution into different fractions in treated sandy soil through the kinetic approach:

Bioavailability of macro or micronutrients is often rate limited by contact time (i.e., residence time) in soils and sediments. Specifically, under Egyptian conditions residence time directly influenced the distribution of $\mathrm{P}$ in soils and subsequently its bioavailability (Zaghloul, 1998). This study tries to evaluate the effect of residence time on $\mathrm{P}$ redistribution into different fractions determined by sequential extraction procedure.

Data in Figure 7 represents $\mathrm{P}$ concentration in the forms of water soluble, exchangeable, $\mathrm{NaOH}$ and $\mathrm{HCl}$ as affected by time of soil incubation. In these figs, plot of time of reaction period in days against $\mathrm{P}$ concentration for these four fractions, the curves were generally straight or concave in the beginning of reaction up to 15 days, the inflection point or the $1^{\text {st }}$ period, and then the curves almost become straight in the rest of reaction time (15-120 days). In some cases, however, the curves become convex in the $1^{\text {st }}$ period particularly in case of $\mathrm{NaHCO}_{3}-\mathrm{P}$ fraction. This result implies that two reaction types take place throughout the entire reaction time of 120 days. In contrast, in hardily available pools depicted in fig 8 , in most cases data plotted take 


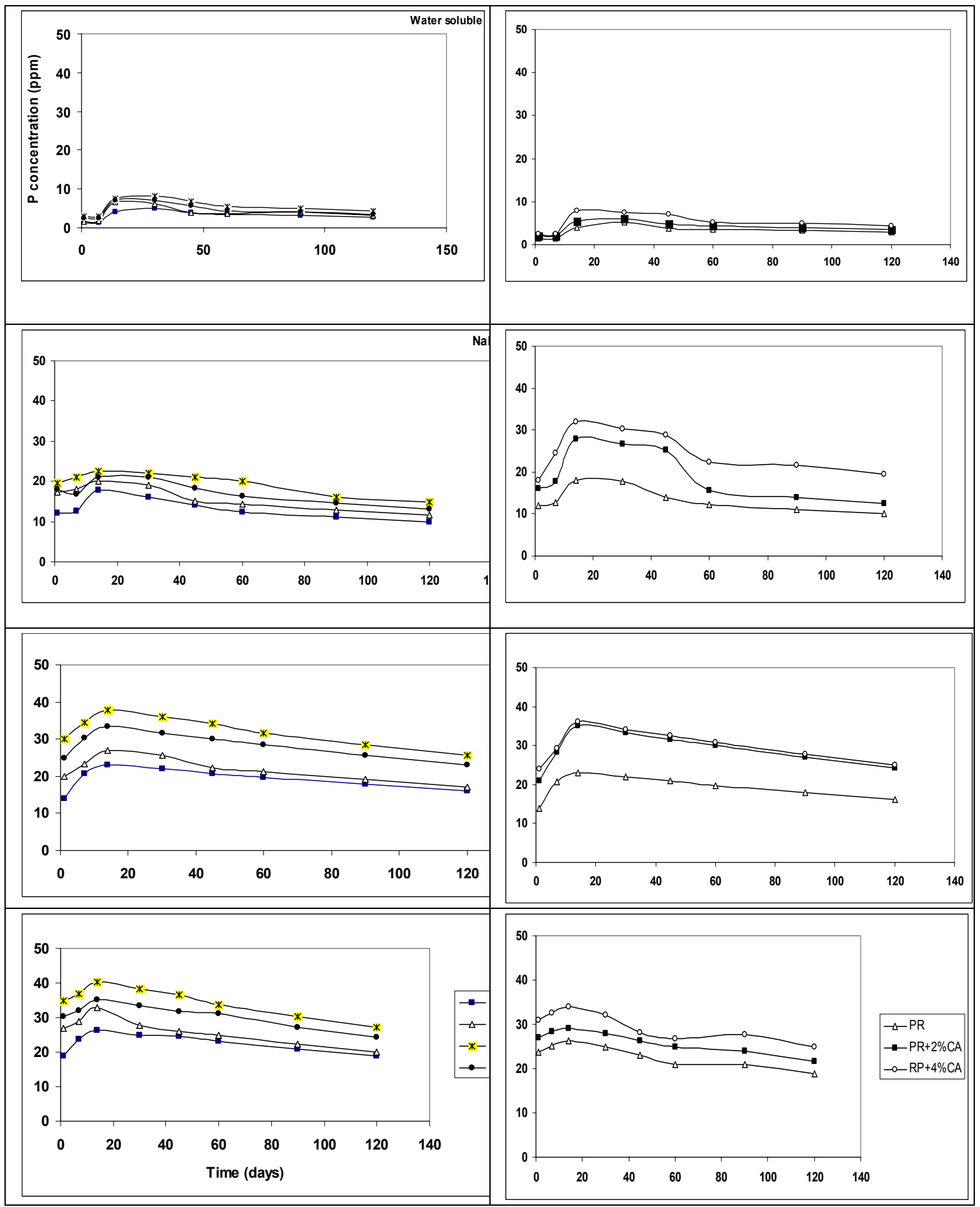

Figure 7. Rate of $\mathrm{P}$ redistribution through the entire reaction time in WS, Exchangeable, $\mathrm{NaOH}$ and $\mathrm{HCl}-\mathrm{P}$ in treated sandy soil. 

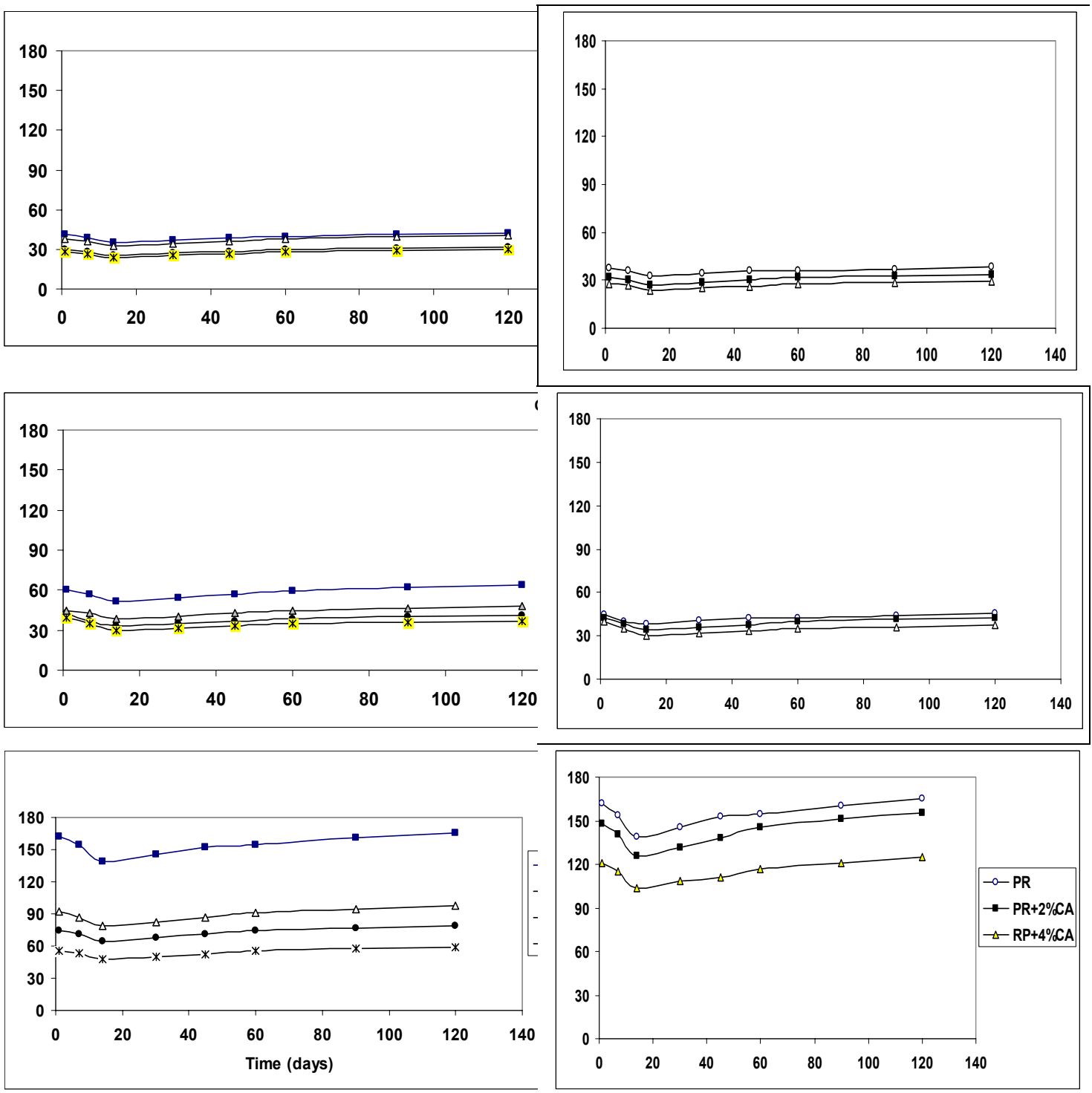

Figure 8. Rate of P redistribution in EDTA, occluded and Residual forms extracted in from treated soils through the entire reaction time.

the convex shape in the $1^{\text {st }}$ period till the inflection point after 15 days this trend was clearly observed in residual pool, followed by straight line at higher reaction period.

Consequently, modified Freundlich model (MFE) in the form of $q=b t^{\mathrm{kd}}$ where $\mathrm{q}$ and $\mathrm{t}$ represent amount of $\mathrm{P}$ in soil system at time $\mathrm{t}, \mathrm{k}_{\mathrm{d}}$ and $\mathrm{b}$ constants were applied, the linear form of this model is: $\log q=b+k_{d} \log t$.

The MFE model and various modified forms of this equation have been applied to experimental data by several researchers (Cooke, 1966; Kuo and Lotse, 1974; Barrow and Shaw, 1975; Evan and Jurinak, 1976; Elkhatib and Hern, 1993; Zaghloul, 1998). This model was applied in this experiment for each period i.e. 1-15 days (the 
$1^{\text {st }}$ period) and $30-120$ days as a (the $2^{\text {nd }}$ period) to each fraction and for different treatments applied.

Data in Table 3, represents the rate constants of MFE for the $1^{\text {st }}$ and $2^{\text {nd }}$ stages, coefficient of determination $\mathrm{R}^{2}$, standard error SE for different treatments applied at different fractions. The coefficient of determination ranged between $0.91^{* *}$ and $0.99^{* *}$ and the SE ranged between 0.01-0.07 in all cases. According to $\mathrm{R}^{2}$ and SE, the tested MFE showed high conformity to describe kinetic data for different treatments.

Concerning the rate constant of MFE in the $1^{\text {st }}$ stage of different fractions, data showed that in water soluble fraction, this constant gave high rate of $\mathrm{P}$ availability in both T2 and T6 while other treatments showed almost equality ranged between 0.33$0.37 \mathrm{mg} \mathrm{kg}{ }^{-1} \mathrm{~min}^{-1}$. In $\mathrm{NaHCO}_{3}-\mathrm{P}$ fraction, again acidification of rock phosphate by $2 \%$ and $4 \%$ citric acid gradually increased $\mathrm{P}$ availability in this fraction, followed by $\mathrm{T} 1$ and then $\mathrm{T} 2$ and $\mathrm{T} 2$. This result perhaps represents the important role of citric acid (CA) in the first period. Although other fraction almost show the same of the importance of CA in readily available forms, the HCL-P fraction showed the least rate of $\mathrm{P}$ availability compared with other fractions tested.

In hardily available forms, data showed that EDTA-P pools have no difference between different treatments; $\left(0.05 \mathrm{mg} \mathrm{kg}^{-1} \mathrm{~min}^{-1)}\right.$. In occluded pool, however, slightly increase was observed ranged between 0.05 and $0.09 \mathrm{mg} \mathrm{kg}^{-1} \mathrm{~min}^{-1}$ in $\mathrm{T} 1$ till T3 and then decrease order in T4, T5 and T6. Worth to mention that residual pool takes the same trend of EDTA-P pool.

In the $2^{\text {nd }}$ stage, data of WS pool indicated that a gradual increase in rate of $\mathrm{P}$ availability was observed. Data in table 3 showed that $\mathrm{K}_{\mathrm{d}}$ of MFE increased from 39, 41, and $47 \mathrm{mg} \mathrm{kg}^{-1} \mathrm{~min}^{-1}$ to $0.50 \mathrm{mg} \mathrm{kg}^{-1} \mathrm{~min}^{-1}$ in $\mathrm{T} 1, \mathrm{~T} 2, \mathrm{~T} 3$ and $\mathrm{T} 4$, where $\mathrm{T} 5$ and T6 showed decreasing order reached to 0.36 and $0.39 \mathrm{mg} \mathrm{kg}^{-1} \mathrm{~min}^{-1}$. In contrast, in $\mathrm{NaHCo}_{3}-\mathrm{P}$, T5 and T6 showed highest values reached to 0.62 and $0.85 \mathrm{mg} \mathrm{kg}^{-1} \mathrm{~min}^{-1}$ against $0.33,0.32,0.31$ and $0.34 \mathrm{mg} \mathrm{kg}^{-1} \mathrm{~min}^{-1}$ in $\mathrm{T} 1$ till $\mathrm{T} 4$ respectively. Among the above mentioned fractions, data indicated that a decreasing order was observed in both $\mathrm{NaOH}-\mathrm{P}$ and $\mathrm{HCl}-\mathrm{P}$ in relation to WS-P and $\mathrm{NaHCo}_{3}-\mathrm{P}$. In the $1^{\text {st }}$ pool most treatments gave $\mathrm{k}_{\mathrm{d}}$ values ranged between 0.22 and $0.27 \mathrm{mg} \mathrm{kg}^{-1} \mathrm{~min}^{-1}$, while the other pool gave $\mathrm{k}_{\mathrm{d}}$ values ranged between $0.15-0.25 \mathrm{mg} \mathrm{kg}^{-1} \mathrm{~min}^{-1}$, the higher values in both pools was detected for T3.

In hardily available pool of EDTA, the $\mathrm{k}_{\mathrm{d}}$ of the $2^{\text {nd }}$ stage had a slight gradually increased in T1, T2 and T3 ranged between 0.10 and $0.13 \mathrm{mg} \mathrm{kg}^{-1} \mathrm{~min}^{-1}$, followed by a steady state condition in T4 and then decreased to 0.12 and $0.07 \mathrm{mg} \mathrm{kg}^{-1} \mathrm{~min}^{-1}$ in T5 and T6. However, the occluded and residual pools gave almost the same values ranged between 0.12 and $0.13 \mathrm{mg} \mathrm{kg}^{-1} \mathrm{~min}^{-1}$ in all treatments with some exception observed in $\mathrm{T} 1$.

\section{CONCLUSIONS}

The results of the present investigation showed that the sequential extraction technique, allows us to clear up phosphorus/ compost relations in soil system of newly reclaimed areas. Data observed indicated that, the association of phosphorus into different pools controlled by residence time and type of treatments applied. Results 
Table 3. Rate constants of modified Freundlich equation, coefficient of determination $\left(R^{2}\right)$ and standard error (SE) in readily available forms (A) and hardly available form $(B)$ of $P$ redistribution in different fractions.

\begin{tabular}{|c|c|c|c|c|c|c|}
\hline \multicolumn{7}{|c|}{ (A)readily available form } \\
\hline \multicolumn{7}{|c|}{ WS-P } \\
\hline Parameters & $\mathrm{T} 1$ & $\mathrm{~T} 2$ & $\mathrm{~T} 3$ & $\mathrm{~T} 4$ & T5 & T6 \\
\hline Stage 1 & 0.41 & 0.48 & 0.34 & 0.37 & 0.37 & 0.48 \\
\hline Stage 2 & $0.39++$ & 0.41 & 0.47 & 0.50 & 0.36 & 0.39 \\
\hline $\mathbf{R}^{2}$ & $0.99 * *$ & $0.98 * *$ & $0.97 * *$ & $0.97 * *$ & $0.99 * *$ & $0.95^{* *}$ \\
\hline SE & 0.04 & 0.05 & 0.04 & 0.05 & 0.01 & 0.07 \\
\hline \multicolumn{7}{|c|}{ NaHCO3-P } \\
\hline Stage 1 & 0.14 & 0.05 & 0.05 & 0.06 & 0.2 & 0.2 \\
\hline Stage 2 & 0.33 & 0.32 & 0.31 & 0.34 & 0.62 & 0.85 \\
\hline $\mathbf{R}^{2}$ & $0.93 * *$ & $0.91^{* *}$ & $0.94 * *$ & $0.98 * *$ & $0.97 * *$ & $0.94 * *$ \\
\hline SE & 0.03 & 0.01 & 0.01 & 0.06 & 0.03 & 0.04 \\
\hline \multicolumn{7}{|c|}{ NaOH-P } \\
\hline Stage 1 & 0.19 & 0.11 & 0.08 & 0.11 & 0.19 & 0.14 \\
\hline Stage 2 & 0.22 & 0.27 & 0.25 & 0.22 & 0.23 & 0.23 \\
\hline $\mathbf{R}^{2}$ & $0.99 * *$ & $0.93^{* *}$ & $0.97 * *$ & $0.99 * *$ & $0.97 * *$ & $0.92 * *$ \\
\hline SE & 0.07 & 0.02 & 0.01 & 0.06 & 0.02 & 0.03 \\
\hline \multicolumn{7}{|c|}{ HCl-P } \\
\hline Stage 1 & 0.12 & 0.07 & 0.05 & 0.04 & 0.03 & 0.03 \\
\hline Stage 2 & 0.2 & 0.22 & 0.25 & 0.23 & 0.17 & 0.15 \\
\hline $\mathbf{R}^{2}$ & $0.99 * *$ & $0.92 * *$ & $0.90 * *$ & $0.91^{* *}$ & $0.99 * *$ & $0.95 * *$ \\
\hline SE & 0.06 & 0.02 & 0.02 & 0.01 & 0.01 & 0.06 \\
\hline
\end{tabular}

(B) Hardly available form

\begin{tabular}{ccccccc}
\hline \multicolumn{7}{c}{ EDTA-P } \\
\hline Stage 1 & $0.05++$ & 0.05 & 0.05 & 0.05 & 0.05 & 0.05 \\
Stage 2 & 0.10 & 0.12 & 0.13 & 0.13 & 0.12 & 0.07 \\
$\mathbf{R}^{2}$ & $0.97^{* *}$ & $0.97^{* *}$ & $0.92^{* *}$ & $0.98^{* *}$ & $0.93^{* *}$ & $0.97^{* *}$ \\
SE & 0.02 & 0.03 & 0.02 & 0.02 & 0.02 & 0.03 \\
\hline \multicolumn{7}{c}{ Occluded-P } \\
\hline Stage 1 & 0.05 & 0.08 & 0.09 & 0.05 & 0.02 & 0.10 \\
Stage 2 & 0.12 & 0.13 & 0.13 & 0.13 & 0.13 & 0.13 \\
$\mathbf{R}^{2}$ & $0.97^{* *}$ & $0.96^{* *}$ & $0.98^{* *}$ & $0.91^{* *}$ & $0.94^{* *}$ & 0.91 \\
SE & 0.02 & 0.01 & 0.02 & 0.03 & 0.01 & 0.02 \\
\hline \multicolumn{7}{c}{ Residual-P } \\
\hline Stage 1 & 0.05 & 0.05 & 0.05 & 0.05 & 0.02 & 0.05 \\
Stage 2 & 0.09 & 0.12 & 0.12 & 0.12 & 0.12 & 0.10 \\
$\mathbf{R}^{2}$ & $0.97^{* *}$ & $0.94^{* *}$ & $0.98^{* *}$ & $0.97^{* *}$ & $0.98^{* *}$ & $0.96^{* *}$ \\
SE & 0.02 & 0.02 & 0.02 & 0.02 & 0.03 & 0.02 \\
\hline
\end{tabular}

++ : stage $1^{\wedge}-1$

T1: treated soil with PR

T4: treated soil with compost $+20 \% \mathrm{PR}$

T2: treated soil with compost $+10 \%$ PR T5: treated soil with $\mathrm{PR}+2 \%$ citric acid

T3: treated soil with compost $+15 \%$ PR T6: treated soil with PR $+4 \%$ citric acid 
also indicated that application of $\mathrm{T} 3$ (compost $+15 \%$ PR) in sand soil increased the readily available pool compared with ether control (PR) or other treatments applied. Moreover, the acidification of PR may increase P-bioavailability compared with PR individually (control treatments).

As a general conclusion increasing of time of soil incubation, led to decrease readily available and increase the hardly ones with different percentages according to treatment applied and the type of fraction studied. The residual pool in all cases take the higher values.

The kinetic study applied in this experiment indicated that the reaction rate of $\mathrm{P}$ redistribution through the entire reaction take tow directions regardless the type of pool. This phenomenon representing different mechanisms controlled $\mathrm{P}$ redistribution under such conditions. However, the more available pools i.e. water soluble, exchangeable, $\mathrm{NaOH}$, and $\mathrm{H} \mathrm{Cl}-\mathrm{P}$ take a reverse trend compared to hardily available pools investigated.

\section{REFERENCES}

Adani, F.; P. L. Genevini; F. Gasperi and G. Zorzi (1997). Organic matter evolution index (OMEI) as a measure of composting efficiency. Compost Sci. Util., 5, 53-62.

Barrow, N. J., and T. C. Shaw (1975). The slow reaction between soils and anions. 5. Effect of period of prior contact on the soil desorption of phosphate from soils. Soil Sci., 119: 311-320.

Bezzola L. C; C. Lopez and N. Barbaro (1994). Effectiveness of different Phosphatic fertilizers measured using labelled super phosphate and phosphorus taken up by plants. Fert. Res. ,39: 31-37.

Bowman, R. A., and C. Cole (1978). An exploratory method for fractionation of organic phosphorus from grassland soils. Soil Sci., 125:95-101.

Chang, S. C., and M. L. Jackson (1957). Fractionation of soil phosphorus. Soil Sci., 84:133-144.

Cooke, I. J. (1966). Kinetic approach to the description of soil phosphate status. $J$. Soil Sci. , 17:56-65.

Cabrera F.; J. Murillo; R. Lopez and J. Hernandez (1991). Fate of phosphorus added with urban compost to a calcareous soil. J Environ Sci Health, B 26: 83-97.

Concepcio' n, S. and A. Delgado (2005). Phosphorus Fractions and Release Patterns in Typical Mediterranean Soils. Soil Sci. Soc. Am. J. ,69:607-615.

De Groot, C. J., and H. L. Golterman (1990). Sequential fractionation of sediment phosphate. Hydrobiologia, 192:143-148.

Dinel, H; M. Schnitzer and S. montet (1996). Compost maturity: Extractable lipids as indicators of organic matter stability. Compost Science \& Utilization, 4: $6-12$. 
Díaz-Espejo, A.; L. Serrano and J. Toja. (1999). Changes in sediment phosphate composition of seasonal ponds during filling. Hydrobiologia, 392:21-28.

Elkhatib, E. A., and J. L. Hern (1993). Kinetics of phosphorus desorption from Appalachian soils. Soil Sci., 145: 222 - 229.

Evan, R. L., and J. J. Jurinak (1976). Kinetics of phosphate release from a desert soil . Soil Sci., 121: $205-211$.

Fardeau, J. C. (1996). Dynamics of phosphate in soils. An isotopic out look. Fert. Res., 45:91-100.

Frei U; T. Candinas and J. M. Besson (1997). Kompost-ein wertvoller Dünger und Bodenverbesserer. Agrarforschung, 4: 463-466

Frossard E.; S. Sinaj; L. M. Zhang and J. L. Morel (1996). The fate of sludge phosphorus in soil-plant systems. Soil Sci Soc Am J., 60: 1248-1253

Golterman, H. L., and A. Booman (1988). The sequential extraction of Ca- and Febound phosphates. Verh. int. Ver. Limnol. 23:904-909.

Golterman, H. L. (1996). Fractionation of sediment phosphate with chelating compounds: A simplification, and comparison with other methods. Hydrobiologia, 315:39-58.

GUPTA S. K. and K.Y. Chen (1975). Partitioning of trace metals in selective chemical fractions of near-shore sediments. CHEN Environ. Lett., 10: 129 158.

Harrison, A. F. (1987). Soil Organic Phosphorus. A review of world literature. CABI Publ., Wallingford, UK.

He, Z. L.; V. C. Baligar; D. C. Martens; K. D. Ritchey and W. D. Kemper (1996). Kinetics of phosphate rock dissolution in acidic soil amended with liming materials and cellulose. Soil Sci. Soc. Am. J., 60, 1589-1595.

Hedley, M. J.; W. B. Stewart, and B. S. Chauhan (1982). Changes in inorganic and organic soil phosphorus fractions induced by cultivation practices and by laboratory incubations. Soil Sci. Soc.

Hickey M. G., and J. A. Kittrick (1984). Chemical partitioning of cadmium, copper, nickel, and zinc in soils and sediments containing high levels of heavy metals. J. Environ. Qual., 13:372-376.

Hieltjes, A. H. M. and L. Lijklema. (1980). Fractionation of inorganic phosphates in calcareous sediments. J. Environ. Qual., 9:405-407.

Huguenin-Elie O.; G. J. D. Kirk, and E. Frossard. (2003). Phosphorus uptake by rice from soil that is flooded, drained or flooded then drained. Eur. J. Soil Sci., 54:77-90.

Kuo, S. and E. G. lotse (1974). Kinetics of phosphate adsorption and desorption by lake sediments. Soil Sci. Soc. Am. Proc., 38: 50 - 54.

Kuo, $\mathbf{S}$ (1995). Nitrogen and phosphorus availability in ground waste and chitinsludge co-composts. Compost Sci. Util., 3: 19-29.

Lookman, R.; H. Geerts, P. Grobet, R. Merckx, and K. Vlassak. (1996). Phosphate speciation in excessively fertilized soil: A 3'P and 21A1MAS NMR spectroscopy study. Eur. J. Soil Sci., 47:125-130. 
Ma, L Q and G. N. Rao (1997). Chemical speciation of trace metals in contaminated soils. J. Environ. Qual., 26:259-264.

McCoy, J. L.; L. J. Sikora and R. R. Weil. (1986). Plant availability of phosphorus in sewage sludge compost. J. Environ. Qual. ,15: 403-409.

McGill, W.B., and C. V. Cole (1981). Comparative aspects of cycling of organic C, N, S, and P through soil organic matter. Geoderma, 26:267-286.

Murillo JM, Cabrera F \& R Lopez (1997). Response of clover Trifolium fragiferum L. cv. 'Salina' to a heavy urban compost application. Compost Sci Util., 5: $15-25$.

Murphy, J. \& Riley, J. P. (1962). A modified single solution for the determination of phosphorus in natural waters. Analytica Chimica Acta, 27, 31-36.

Paniagua, A.; M. J. Mazzarino; D. Kass, L. Szott and C. Farnadez (1995). Soil phosphorus fractions under five tropical agroecosystems on a volcanic soil. Aust. J. Soil Res., 33:311-320.

Pommel B (1982). Aptitude de plusieurs déchets urbains à fournir du phosphore aux cultures. Agronomie, 2: 851-857.

Rodolphe, G; E. GOMEZ and B. PICOT (2000). Phosphorus and organic matter in wetland sediments: analysis through gel permeation chromatography (GPC). Agronomie, 20: 567-576.

Saleque, M. A., and G. Kirk (1995). Root-induced solubilization of phosphate in the rhizosphere of lowland rice. New Phytol., 129:325-336.

SAS Institute (1985). SAS/STATTM guide for personal computer. 6th Edn, SAS Institute Inc., Cary, NC.

Sharpley, A. N. (1985). The selective erosion of plant nutrients in runoff. Soil Science Society of America Journal, 49(6):1527-1534.

Sharpley, A. and B. Moyer (2000). Phosphorus forms in manure or compost and their release during simulated rainfall. Journal of Environmental Quality, 29(5):1462- 1469.

Sikora, F.; J. Copeland; P. Mullins and J. Bartos (1991). Phosphorus dissolution kinetics and bioavailability of water - insoluble fractions from monoammonium phosphate fertilizers. Soil Sci. Soc. Am. J. , 55 : 362 - 368 .

Sui, Y.; M. Thompson and C. Shang. (1999). Fractionation of phosphorus in a Mollisol amended with biosolids. Soil Sci. Soc. Am. J., 63:1174-1180.

Tessier, A.; P. Campbell and M. Bisson (1979). Sequential extraction procedure for the speciation of particulate trace metals. Analytical Chemistry, 51: 844-851.

Torrent, J.; V. Barron and U. Schwertmann (1990). Phosphate adsorption and desorption by goethite differing in crystal morphology. Soil Sci. Soc. Am. J., 54:1007-1012.

Zaghloul, A. M. (1998). Kinetics of phosphate releases in some soils of Egypt. Ph. D. Thesis, Soil Dept., Faculty of Agriculture, Ain Shams Univ. Egypt.

Zaghloul, A. M; Camilia, El-Dewany and R. A. Yousef (2006). Distribution of $\mathrm{Pb}$ and $\mathrm{Zn}$ in some Egyptian contaminated soils as affected by time of exposure and source of pollutants. Pakistan J. applied Sci. Res. (In press). 


\title{
تأثير زمن التفاعل على توزيع الفوسفور من بعض الأراضي المعاملة

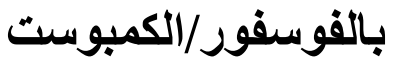

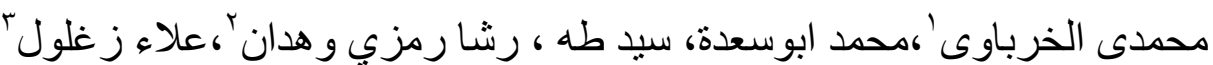

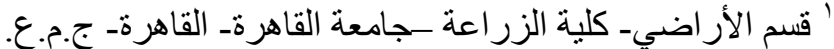

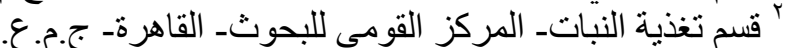

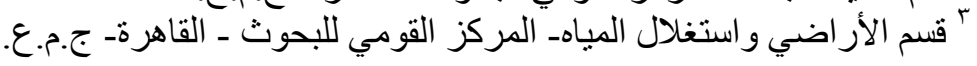

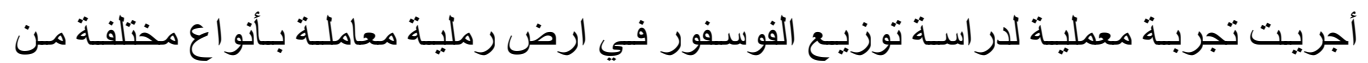

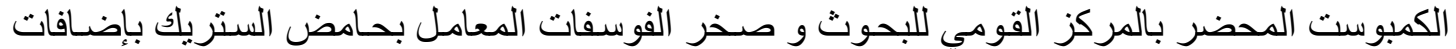

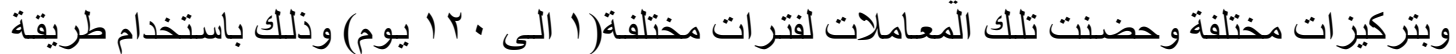

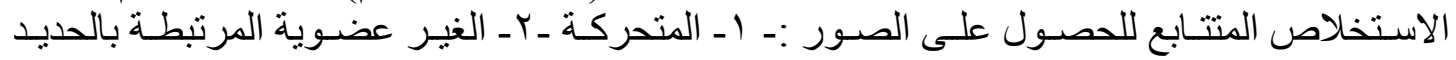



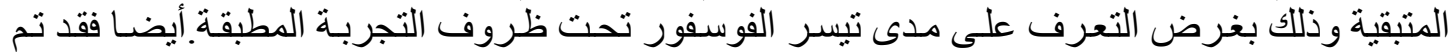
أجر اء در اسة كينيتيكية لمعرفة معدل انطلاق الفوسفور من المعاملات المختلفة بغرض الرف الربط بين معدل

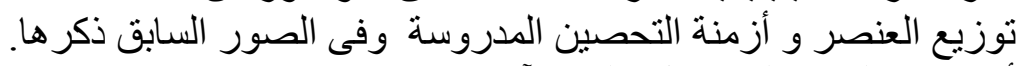
أوضحت النتائج المتحصل عليها الآتي:-

استخدام الكمبوست المضاف بنسبة تحتوى على 0 \% \% صخر فوسفاتى (أحسن معاملة على مدار

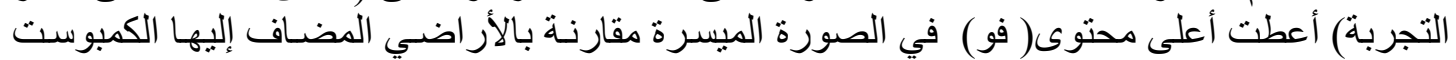

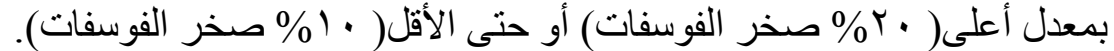

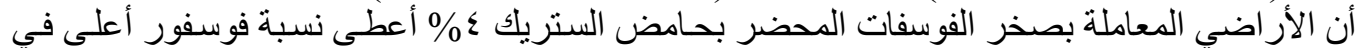

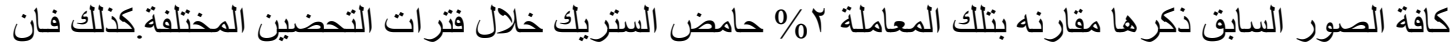

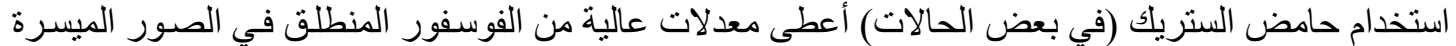

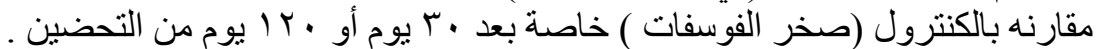



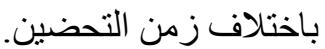

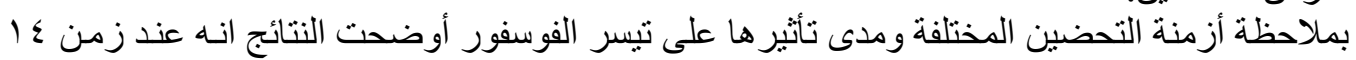

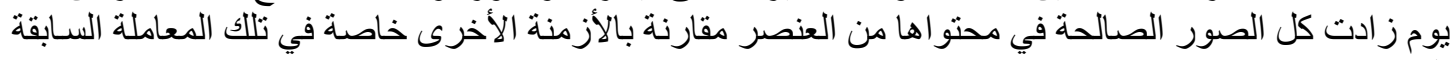

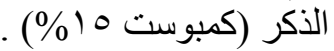

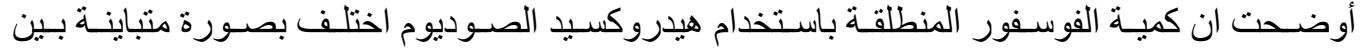

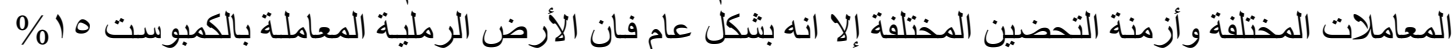
صخر الفوسفات أعطت مرة أخرى افضل النتانت النتائج.

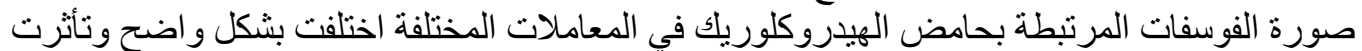

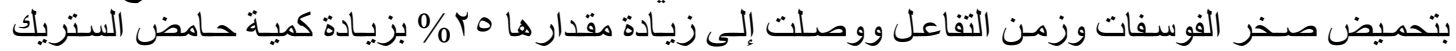
الدر اسة الكينيتكية التي طبقت في هذا البحث وضحت أن تركيز الفوسفات خلال زمن التفاعل المدروس

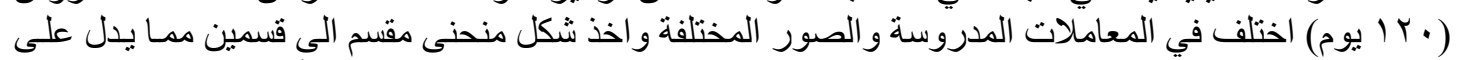

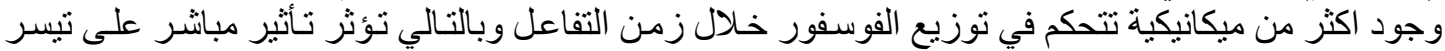

